\title{
Applying Theory to Real-World Problems: Integrating Service-Learning into the Industrial Engineering Capstone Design Course
}

\author{
Sinan Onal \\ Assistant Professor \\ Department of Mechanical and Industrial \\ Engineering \\ Southern Illinois University \\ sonal@siue.edu
}

\author{
Joel Nadler \\ Associate Professor \\ Department of Psychology, Industrial- \\ Organizational Psychology \\ Southern Illinois University \\ jnadler@siue.edu
}

\author{
Megan O'Loughlin \\ Graduate Student \\ Department of Psychology, Industrial-Organizational Psychology \\ Southern Illinois University \\ molough@siue.edu
}

\begin{abstract}
The Senior Capstone Design course is one of the most important in the four-year industrial engineering curriculum. The course concludes the Industrial Engineering (IE) student's undergraduate studies, satisfying the Accreditation Board of Engineering and Technology's (ABET) requirements and allowing students to work in collaborative teams. Service-learning is an educational approach that integrates academics with community service; students apply classroom content to community problems, thereby enhancing learning while providing needed services to underserved populations. The proposed service-learning aims to address all the ABET requirements as well as involve a collaborative research partnership in which students conduct research to meet a community organization's needs. The deliverables for this project include (1) a detailed report describing the design, analysis, performance, and alternative approaches, (2) the physical prototype developed by the team, and (3) a network of experienced young professionals who can be recruited as employees for local community organizations. A pretest and post-test were administered at the beginning and end of the semester to assess learning over time. These tests were specifically assessing student confidence in ability to transition smoothly from academia to professional environments. In addition, a midsemester survey was used to gather detailed information about stakeholder reactions, learning, and behaviors.
\end{abstract}

Index Terms - Assessment, community partners, industrial engineering, service-learning.

\section{INTRODUCTION}

The Senior Capstone Design course is one of the most important in the four-year industrial engineering curriculum. The course concludes the Industrial Engineering (IE) student's undergraduate studies, satisfying the Accreditation Board of Engineering and Technology's 
International Journal for Service Learning in Engineering, Humanitarian Engineering and Social Entrepreneurship Vol. 12, No. 2, pp. 57-80, Fall 2017

ISSN 1555-9033

(ABET) requirements and allowing students to work in collaborative teams. ${ }^{1}$ The ideas for team projects are usually generated by students under the course instructor's guidance to avoid students working on unrealistic projects requiring assumptions for completing engineering analyses that may result in unworkable completed projects. Although the Senior Capstone Design course currently offers integrating product/service design skills, team works, and critical thinking, students would gain additional benefits by altering the course format to one that incorporates service-learning.

Service-learning by integrating community engagement into the senior design course offered by the IE program has been implemented in this study. The proposed course format allows students to put theory into practice and understand the complexities of practical problem solving in real-world situations, thereby preparing them to become effective civic leaders. The additional benefits of this learning model for students include providing students with a multidisciplinary team experience, professional responsibility, leadership opportunity, expanded view of engineering in terms of community engagement, alternative learning environment for those with learning styles not well-suited to traditional lectures, personal engagement with local community, and ability to learn job skills and prepare for careers after college. This model also benefits the local community, the department and school as well as the faculty. Faculty benefits include enhancing coursework with real applications and hands-on experience, providing opportunities for building community partners, and making an impact on the community. The local community benefit from access to technical resources, affordable high-quality technical services, solutions to specific community problems/challenges, long-term partnerships with the college, increased awareness of the local community within the student population, and ability to energize the community by involving young people. The department and school benefit by exceeding ABET criteria as well as providing real cases and applications for the curriculum and enhancing education quality, public relations and perception, and potential for untapped funding. ${ }^{2}$

Service-learning is an educational approach that integrates academics with community service; students apply classroom content to community problems, thereby enhancing learning while providing needed services to underserved populations. Research has shown that servicelearning enhances classroom learning, and it is consistent with theories for increasing student retention. ${ }^{3}$ Service-learning differs from that in traditional courses in that it provides (1) an opportunity to complement traditional coursework with learning environments that speak to the diverse learning styles of students, (2) a more holistic approach to learning, and (3) a connection with social contexts and real-world community issues.

Service-learning can take several forms, including direct service, indirect service, a consultant model, and community-based research. ${ }^{5}$ In this research, a new capstone course format is proposed using the community-based research form of service-learning in the Department of Mechanical and Industrial Engineering at Southern Illinois University, Edwardsville (SIUE). The proposed service-learning addresses all of the ABET requirements as well as involve a collaborative research partnership in which students conduct research to meet a community organization's needs. Thus, students work beyond the traditional classroom setting to apply technical knowledge to actual engineering problems. The goals of this proposed course format are to meet course objectives and ABET program outcomes as well as to enhance student learning through service-learning based projects. Thus, the impact of these projects on student learning is also examined. The proposed service-learning project has been developed, 
implemented, and evaluated with a cohort of 35 undergraduate senior engineering students in the spring semester of 2017. In addition to the direct impact on the cohort, approximately 450 high school students and 120 additional undergraduate engineering students are expected to learn new engineering content, enhancing recruitment and retention efforts at SIUE, respectively.

Service-learning have been integrated into the capstone design course based on Howard's model. ${ }^{6}$ This model indicates that the community service experience must be relevant to the academic course of study and emphasizes the integration of both experiential and academic learning, with each strengthening the other as shown in Figure 1. The two following fundamental components have been designed before incorporating this model into the existing curriculum.

- IE Senior Design Website: A functional website is essential for the success of the proposed project. It provides the means for local communities to submit project ideas as well as for students to present completed projects to the community for review.

- Pre-class informational workshops: Because the IE senior capstone design course spans only one semester, pre-class workshops were necessary before students can begin working on projects. After completing the workshops, the students were expected to create project teams. The teams were responsible for selecting their own projects using the "project pool" and contacting the relevant organizations in the local community using the contact information provided by the instructor.

The course was conducted using the following four components.

1. Formal lectures: Formal lectures were scheduled for fifty minutes three times every week during the semester and based on a relevant topic of the week. Formal meetings between the instructor and students were also conducted to answer questions and offer feedback based on student progress. Additionally, students participated in weekly team meetings and submitted memos outlining the outcome of these meetings, covering their weekly progress and the following week's plan.

2. Guest lectures by invited professionals: Every other week, a professional who has expertise on the relevant topic of the week and who has volunteered to donate time to help students attended class to present a brief lecture on a topic from the perspective of industry. The guest lecturers provided their hands-on experience and tips to direct students toward common practices in the market and resolutions to challenges they have overcome. Each individual student submitted a journal about these talks. These journals were not a summary of the lectures, but a brief review of the talk and an in-depth analysis of how the topic discussed could be applied to students' projects, professional or personal career. Journals were due a week after the corresponding lecture.

3. Site visits: The instructor visited the local community organizations along with the project teams to observe the project problems firsthand and discuss possible solutions with local community leaders. The project teams continued meeting with the community organizations to share their suggested solutions and implement the agreed upon revisions. The community organizations' responsibilities were to (1) identify a need or opportunity, (2) assign a technical or managerial person responsible for giving the team appropriate guidance, operations and economic information, and plant access (during the semester, 
this person spend 2-4 hours per week interacting with team members), and (3) arrange for an appropriate level of management to receive and consider the team's formal proposal, interim report, tentative results, conclusions, and final design.

4. Service-learning projects: One type of project was considered, Product Design, which focuses on developing or improving specific products or processes to fulfill the need of the local community organization. This project aims to provide solutions for reducing costs, improving performance, introducing new products, and initiating new markets. This combination of technical, design, and commercial requirements provides students with firsthand, relevant industry experience.

The deliverables for this project includes (1) a detailed report describing the design, analysis, performance, and alternative approaches considered during the development/design of the project, (2) the physical prototype developed by the team, when applicable, upon completion of the prototype's use by the team members, and (3) a network of experienced young professionals who can be recruited as employees for local community organizations.

The term project has three phases-or design reviews. Each team submitted a formal report and participated in a design review on the project, following the rubrics provided to students. The instructor provided detailed feedback to students on their design review draft, after which they revised and submitted as design review 2, and so on. Each team presented their design reviews to the entire class, and they had 10 minutes for their presentation, with 3 minutes for questions. The reviews addressed the background for the problem, the specific decision situation, any assumptions made, the analysis used to answer the decision questions, and the appropriate results. For final project prototypes, once the team designs were approved for fabrication, teams were scheduled at the lab and the designs were fabricated using a rapid prototyping machine and other necessary equipment. 


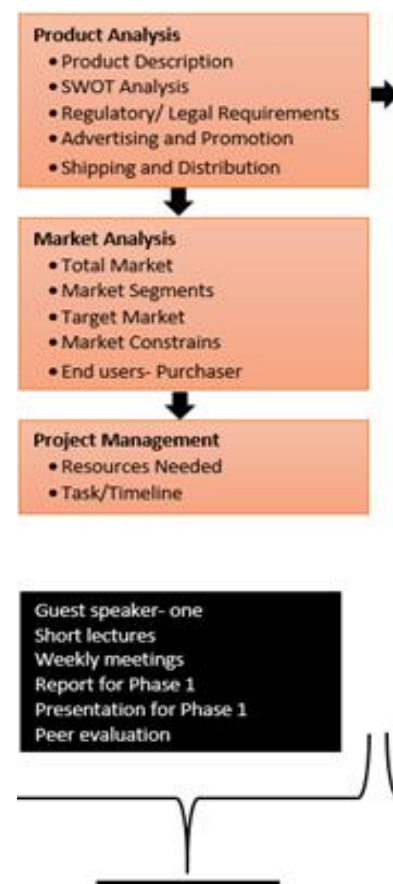

PHASE 1

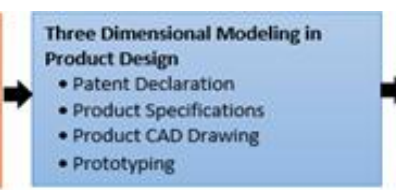

Facility Location

- Selection of Facility Location

- Facility Planning

- Selection of Manufacturing System

- Prototyping

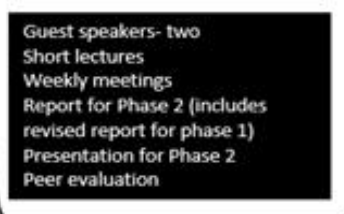

PHASE 2

- Personnel Requirements

- Personnel Functions

Management Structure - Profile of Key Executives - Ownership Structure - Exit Strategr

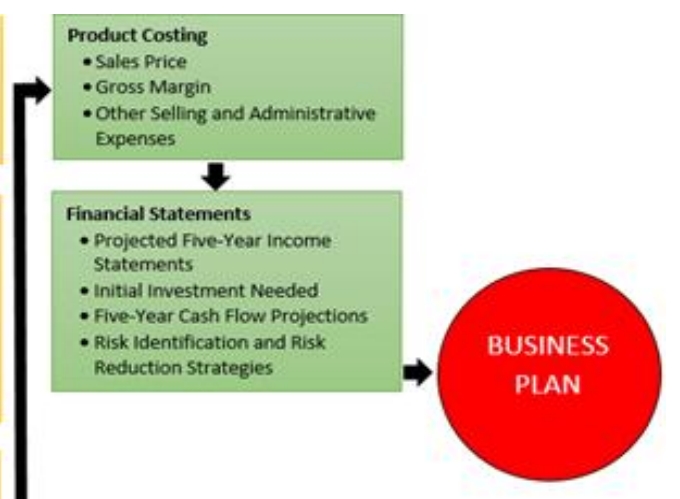

- Organizational Chart

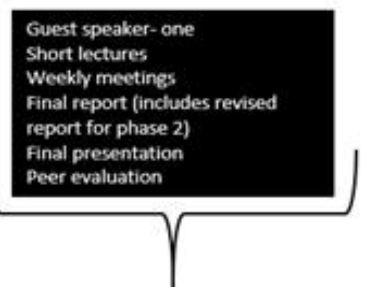

PHASE 3

\section{FIGURE VII \\ SENIOR DESIGN COURSE PROCESS}

\section{PROJECT IMPLEMENTATIONS}

After contacting a few community partners in Edwardsville, IL, three service-learning projects were agreed upon with two community partners: A local retail store and a non-profit agency, which employs people with disabilities for tasks such as packaging pasta, erasing the wrong labels on a variety of products or boxing of ammunition. The instructor of the senior design course from the IE department worked with each of the community partners in detailing the project descriptions and integrating the project into the curriculum. It was agreed upon that the projects should have provided community engagement opportunities for the students and necessitated industrial engineering skills to be accomplished. The selected projects detailed below allowed our students to not only interact with the local community but also apply their knowledge and technical skills to address some of the real-life problems in the community. A total of 35 undergraduate senior students participated in these community-based projects. Table I provides more detailed information on the courses and the corresponding the service-learning projects. 
International Journal for Service Learning in Engineering, Humanitarian Engineering and Social Entrepreneurship Vol. 12, No. 2, pp. 57-80, Fall 2017

ISSN 1555-9033

PROJECTS INTEGRATED INTO THE SEBIOR DESIGN COURSE

\begin{tabular}{|l|c|c|}
\hline \multicolumn{1}{|c|}{ Projects } & Community Partners & $\begin{array}{c}\text { Number of students } \\
\text { participated }\end{array}$ \\
\hline $\begin{array}{l}\text { A Workplace Optimization by using Assistive } \\
\text { Technology for Ammunition Packaging }\end{array}$ & Challenge Unlimited Inc & 4 \\
\hline Stocking Carts Design for a Local Retail Store & Schnucks & 23 \\
\hline Smart Cart Design for a Local Retail Store & Schnucks & 8 \\
\hline
\end{tabular}

\section{Project 1: A Workplace Optimization by using Assistive Technology for Ammunition Packaging}

Project Description: As a non-profit agency, Challenge Unlimited Inc employs people with disabilities for tasks such as packaging pasta, erasing the wrong labels on a variety of products, or boxing of ammunition. Although most of these tasks are temporary, packaging of ammunition of Winchester Ranger boxes holding rifle bullets is a regular task required of employees with disabilities in this agency. Each box holds 25 bullets, placed $5 \times 5$. Because of the shape of the bullets and the necessity of preserving space in each box, currently each bullet is placed one by one in opposite direction with the bullets touching. In other words, the employees with disabilities need to put one row of 5 bullets starting with placing one bullet upside down, and then the next downside up, while they need to start the second row with a bullet upside down and continue by reversing the position of the bullet. The employees get paid by the number of boxes they pack. However, having moderate intellectual disability, colitis, hyperlipidemia, bilateral carpal tunnel syndrome, hypothroidism, GERD, depression NOS and anxiety NOS, Amy Hanold, our subject of expert, experiences difficulties completing the task along with other employees of the Challenge Unlimited Inc.

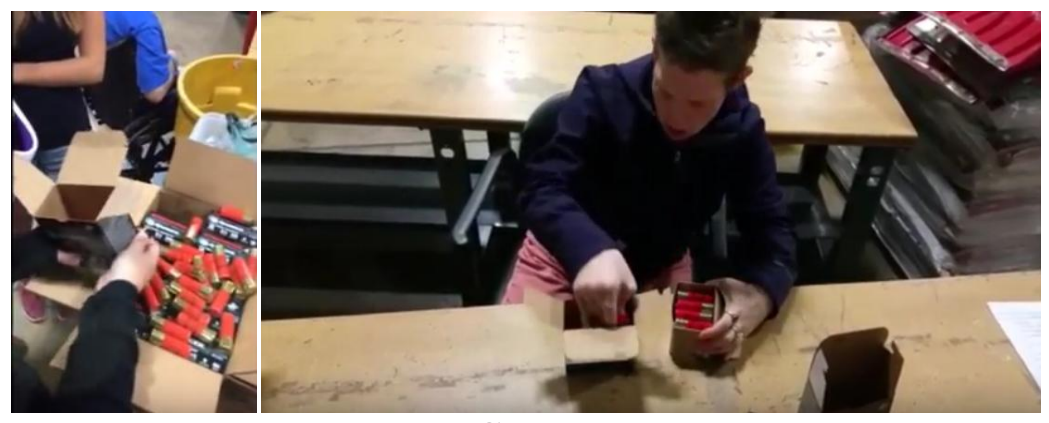

FIGURE I

THE CLIENT IS DESCRIBING THE PROCESS

Solution: The primary contribution of this project was the development and fabrication of an assistive device created for enhancing the productivity in the workplace by simplifying the task of packaging ammunition by the employees with disabilities. The students designed a device called "Tolt" by using 3D modeling CAD program, NX 8.0, in order to fabricate the device as seen in Figure 1. The 3D model prototype was created as a modular. The device is created of five main parts and two minor parts. Main parts are: inner base, slider, outer base, lid and legs. Minor parts are: sticks for inner base and sticks for slider. The prototypes were created by 3D printing 
International Journal for Service Learning in Engineering, Humanitarian Engineering and Social Entrepreneurship Vol. 12, No. 2, pp. 57-80, Fall 2017

ISSN 1555-9033

using acrylonitrile butadiene styrene (ABS) plastic which is a strong, durable, and economic It has been observed that this device enabled the task of assembling the pieces of bullets to be much easier, and it is much more effective than the current method.
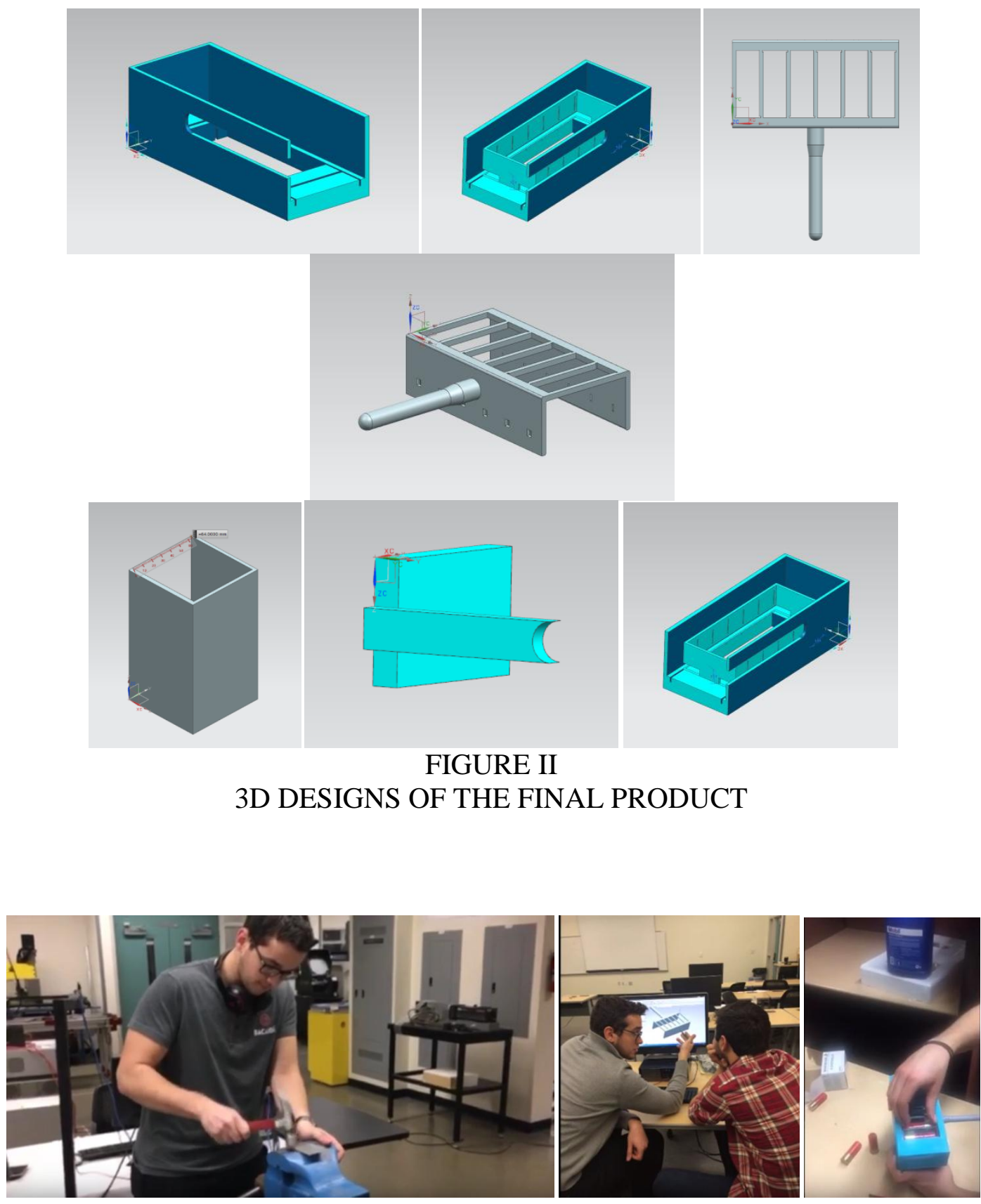

FIGURE III

THE PRODUCT MAKING PROCESS 


\section{Project 2: Stocking Carts Design for a Local Retail Store}

Problem Description: The ideal situation for retail stores is all stores should follow the same standard operating procedures when it comes to stocking shelves and producing tables. However, variables like back room layouts, aisle width and delivery times often have great influence on how crews work their loads. Thus, what may be an efficient process in one store may totally be inefficient at another store. As a result, some stores with reliable delivery schedules and wide aisles are stocking shelves at a rate of 50 cases/hour; while other stores who never know when their loads might come in and have narrow aisles have a hard time hitting 30 cases/hour. In the first case, these stores can plan their manpower accordingly and can pull full pallet quantities out into the floor, especially if their deliveries happen overnight. In the second case, these stores may be caught short handed and then have to double handle their loads into narrow carts because they have narrow aisles that cannot fit full sized pallets. To help make the stocking process more uniform and more efficient, group of students have been asked to design and fabricate a fleet of stocking carts that can far exceed the 50 case/hour rate in any store regardless of the delivery schedule or the store layout. In conclusion, if there is enough productivity improvement through the use of these carts, then the proposed cart can pay for itself within a year. The productivity improvement would have to cover the price of the carts as well as any additional cost in the supply chain, specifically distribution operations.

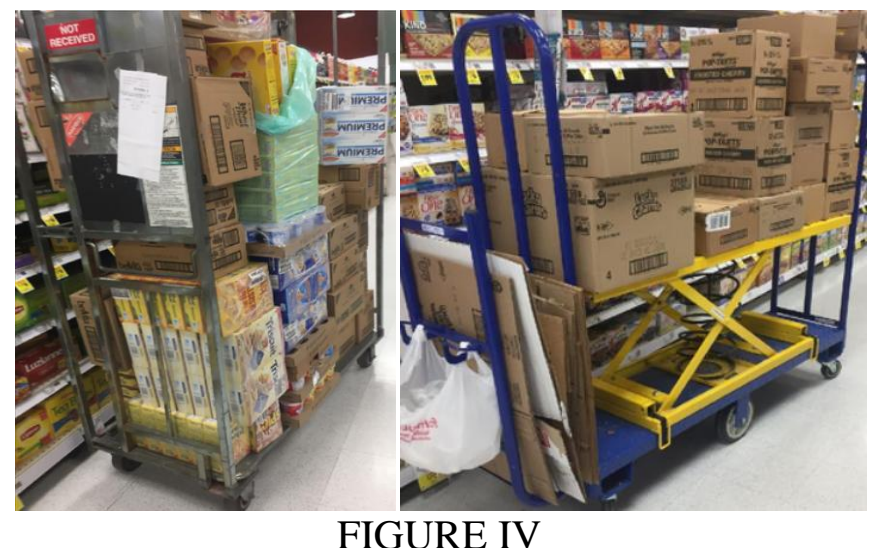

THE PRODUCT MAKING PROCESS

Solution: The Modular Cart concept is a design idea that focuses on appealing to every customer rather than appealing only to one specific set of customers. The design includes numerous removable/attachable parts that can be assembled in approximatel five different combinations. These five combinations cover the most popular storage cart styles seen in many department stores, but does not limit the assembly combinations. The Modular Cart's design allows customers to assemble the cart into a design that will fit their stocking needs. 

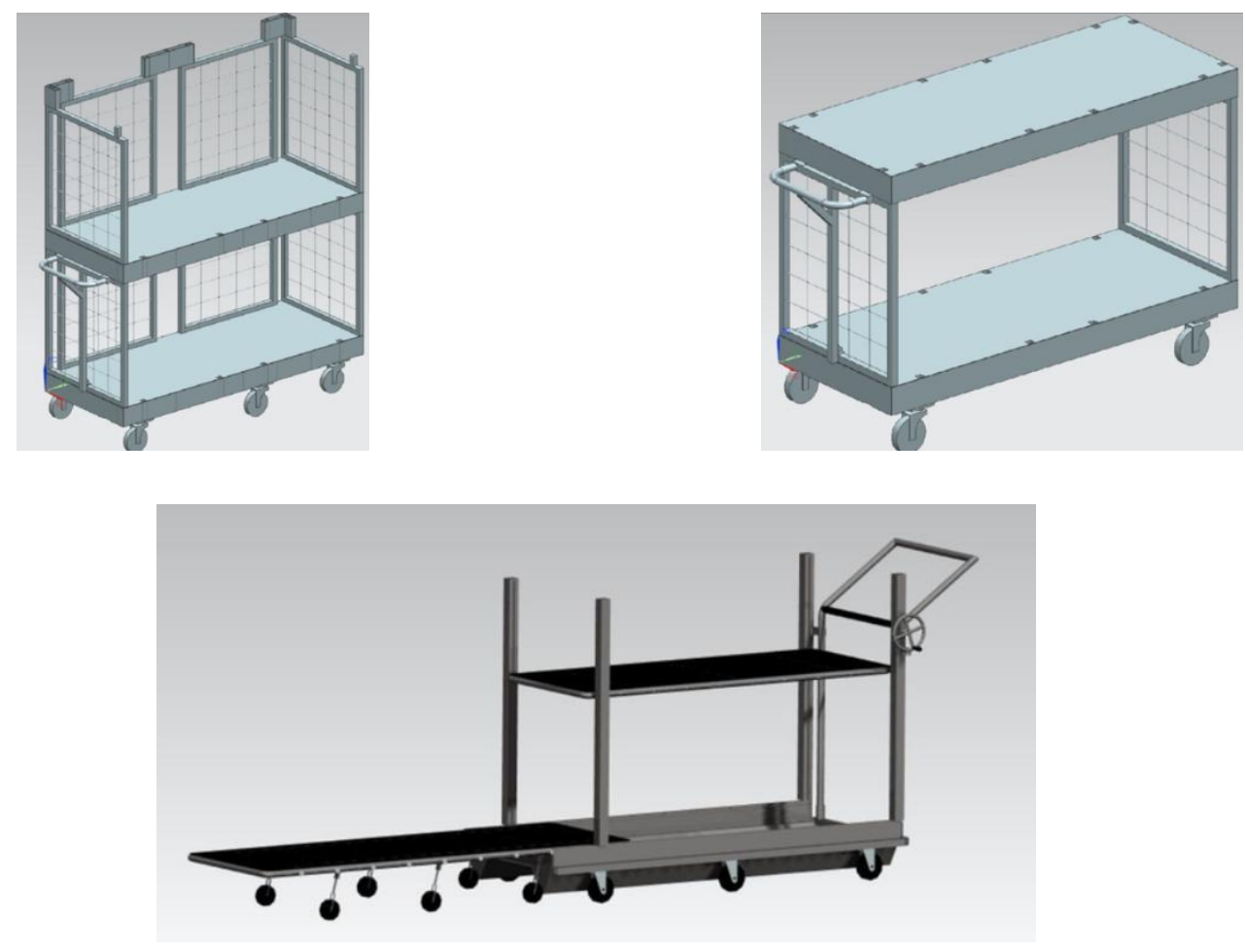

FIGURE V

THE NEW STOCKING CART ALTERNATIVES DEVELOPED BY STUDENTS

\section{Project 3: Smart Cart Design for a Local Retail Store:}

Problem Description: Customer satisfaction and seamless shopping experience for their customers are among the top priorities of grocery stores. For many years Schnucks has prided itself as being the "The Friendliest Store in Town", which meant they spent a lot of time instilling strong customer service values in all of their teammates. However, in recent years, new generation customers have redefined what seamless means, and some have opted to minimize the amount of human interaction that shopping requires. Although the store is proud of their friendly staff, the existence of friendly staff has less value to this clientele than the possibility of timeefficient shopping - the criteria for a seamless shopping experience for this new generation. As a result, some of their competitors as well as them have been implementing more self-scanning technology. Some companies that were not their competitors in past now have stores that read RFID tags and check customer out when customer leave the building with no human interaction or at all. To appeal to the characteristics and needs of this newer generation of customers, group of students have been asked to design a "smart cart" that can provide the kind of seamless shopping they seek. This "smart cart" needs to reasonable in price, ease of implementation and maintenance. It needs to prove itself as a good investment for the grocery store that we collaborate with for this project both in the short run and the long run.

Solution: The newly developed smart cart aims to minimize the human interaction between customers and staff and provide the fastest and cheapest way of shopping possible. "SmartCart" 
has a smart screen that helps customers to find the locations of the products and make payment by using this smart screen via credit or debit card. When a customer enters the shop, he or she will be able to take smart screen located next to the shopping carts. The customer can locate it anywhere on the shopping cart by using the locks located at the bottom of the smart screen. In addition, it has some physical improvements that help customers to use it.
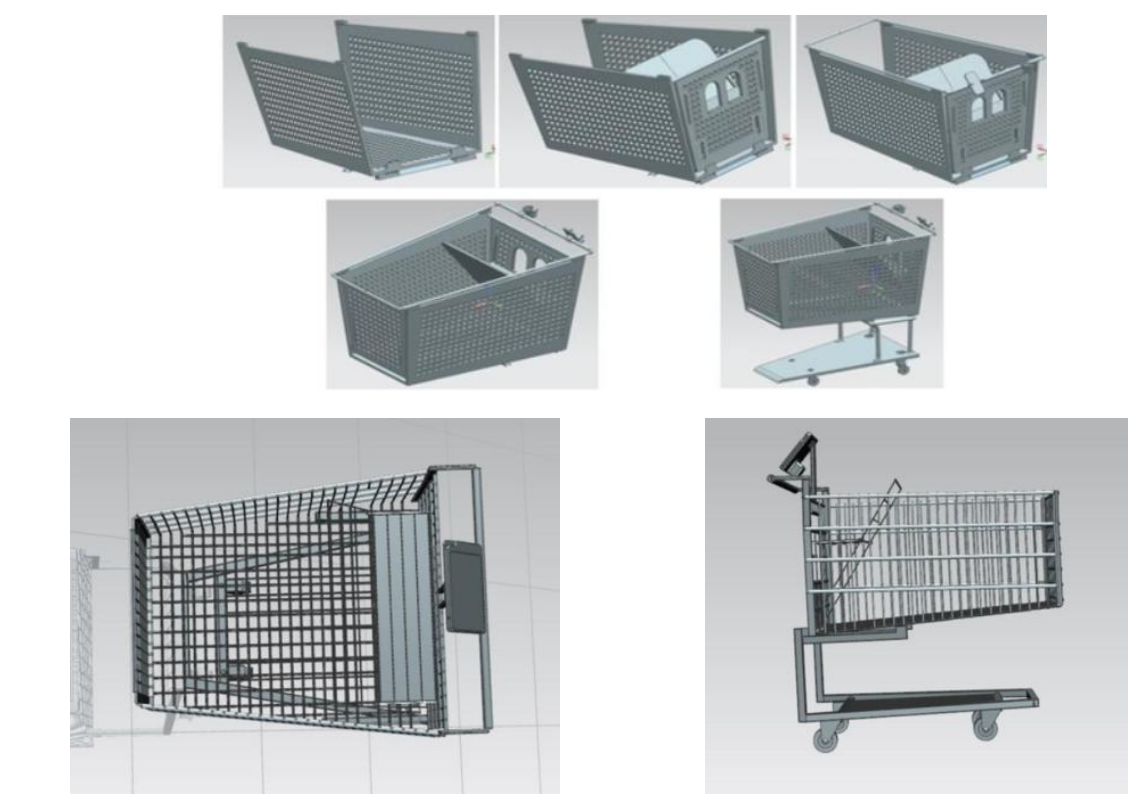

FIGURE VI

THE NEW SMARTCART ALTERNATIVES DEVELOPED BY STUDENTS

\section{ABET PROGRAM OUTCOMES MET}

ABET Program Outcomes describe what students are expected to know and be able to do by the time of graduation. These relate to the skills, knowledge, and behaviors that students acquire in their matriculation through the program as shown in Table II. ${ }^{7}$ The ABET Program Outcomes for Mechanical and Industrial Engineering Department are as follows:

a) an ability to apply knowledge of mathematics, science and engineering

b) an ability to design and conduct experiments, as well as to analyze and interpret data

c) an ability to design a system, component, or process to meet desired needs within realistic constraints such as economic, environmental, social, political, ethical, health and safety, manufacturability, and sustainability

d) an ability to function on multidisciplinary teams

e) an ability to identify, formulate, and solve engineering problems

f) an understanding of professional and ethical responsibility

g) an ability to communicate effectively ( $3 \mathrm{~g} 1$ orally, $3 \mathrm{~g} 2$ written)

h) the broad education necessary to understand the impact of engineering solutions in a global, economic, environmental, and societal context

i) a recognition of the need for, and an ability to engage in life-long learning

j) a knowledge of contemporary issues 
k) an ability to use the techniques, skills, and modern engineering tools necessary for engineering practice.

The specific course outcomes for the Senior Capstone Design course are as follows;

1. Integrate product/process/tooling design skills acquired through previous coursework to design and fabricate a prototype of a complex product.

2. Synthesize analytical market, production system, and cost estimation evaluation and design skills acquired through previous coursework to perform commercialization activities associated with the product of item 1 above.

3. Conduct effective meetings, organize and participate in effective teams, and develop and deliver effective reports and presentations.

4. Appreciate the necessity for the continual upgrade of engineering and technical knowledge.

TABLE II

COURSE SPECIFIC OUTCOMES

\begin{tabular}{|c|c|c|c|c||}
\hline Student Outcomes & \multicolumn{5}{|c||}{ Course Specific Outcomes } \\
& 1 & 2 & 3 & 4 \\
\hline a. & $\checkmark$ & & & \\
\hline b. & & & & \\
\hline c. & & & & \\
\hline d. & & & & \\
\hline e. & & & & \\
\hline f. & & & & \\
\hline g. & & & & \\
\hline h. & & & & \\
\hline i. & & & & \\
\hline j. & & & & \\
\hline k. & & $\checkmark$ & & \\
\hline
\end{tabular}

\section{EVALUATION METHODOLOGY}

The surveys were drafted by co-authors and were then approved by the instructor. The survey respondent pool consisted of 35 students enrolled in the senior capstone design course. Surveys measuring reactions, learning, and behaviors were sent out pre- and post-program to all participants targeted. Results were examined using a pre-test/post-test repeated measure design analyzing quantitative and qualitative measures. Qualitative methods were analyzed for broad themes to provide further narrative feedback to the quantitative measures.

The pre-test and post-test were administered to students in-person. The survey opened with 17 items measuring confidence in technical skills, applying engineering techniques to real-world problems, working with others, communicating ideas, and generating innovative ideas (see Appendix A). The survey concluded with two open-ended questions. These questions prompted students to explain what they feel most and least confident about as they transition from their education to their career. The same survey was administered again at the end of the semester to 
International Journal for Service Learning in Engineering, Humanitarian Engineering and Social Entrepreneurship Vol. 12, No. 2, pp. 57-80, Fall 2017

ISSN 1555-9033

assess learning during the course. Results of the scaled and open ended questions were compared to assess differences across time.

Between the pre- and post-tests, a mid-semester survey was also used to collect information about student experiences. A series of open-ended questions was drafted. This survey was hosted on a secure third party website and distributed to students using a link via email. Open-ended questions were used to gather richer qualitative data to supplement quantitative measures. The survey was open for a period of 25 days. Responses were analyzed thematically for trends. Results of the pre-test, post-test, and mid-semester survey are reported below.

\section{SURVEY RESULTS}

The pre- and post-test survey asked students to rate their confidence in areas that were identified by investigators as important for the industrial engineering students' transition from academia to the workplace. For each of these questions, respondents indicated agreement or disagreement on a 5 point Likert-like scale ranging from $1=$ "Not Confident at All" to $5=$ "Extremely Confident". The mid-point of the scale, 3.0 represents neither high nor low confidence. Thus, scores under 3.0 indicate lower levels of confidence in each area while scores greater than 3.0 indicate greater levels of confidence.

There were statistically significant differences between the pre- and post-test in several areas, indicating increases in student confidence over the semester (see Table 1). For creating and adapting complex products and services, there was a significant increase in confidence ratings from the pre-test $(\mathrm{M}=3.77, \mathrm{SD}=.81)$ to the post-test $(\mathrm{M}=4.03, \mathrm{SD}=.75) ; \mathrm{t}(34)=2.49, \mathrm{p}=$ .02. Overall, students also felt more confident applying engineering techniques and design procedures to solve open-ended problems at the end of the semester $(\mathrm{M}=4.23, \mathrm{SD}=.77)$ than they had at the beginning $(\mathrm{M}=3.69, \mathrm{SD}=.83) ; \mathrm{t}(34)=3.93, \mathrm{p}=.01$. A significant change was also found for ability to generate new ideas for products and services, with statistically significant increases in overall confidence between the pre-test $(\mathrm{M}=4.00, \mathrm{SD}=.77)$ and post-test $(\mathrm{M}=4.29$, $\mathrm{SD}=.67) ; \mathrm{t}(34)=2.25, \mathrm{p}=.03$. There was a significant increase in student confidence in ability to adapt existing products/services using engineering techniques between the pre-test $(\mathrm{M}=3.71$, $\mathrm{SD}=.83)$ and the post-test $(\mathrm{M}=4.11, \mathrm{SD}=.76) ; \mathrm{t}(34)=2.91, \mathrm{p}=.01$. A significant change was also found for applying engineering techniques and skills to solve real-world problems, with statistically significant increases in overall confidence between the pre-test $(\mathrm{M}=3.89 \mathrm{SD}=.80)$ and post-test $(\mathrm{M}=4.26, \mathrm{SD}=.82) ; \mathrm{t}(34)=2.41, \mathrm{p}=.02$. Lastly, there was also a significant change between the pre- $(\mathrm{M}=3.85, \mathrm{SD}=.86)$ and the post-test $(\mathrm{M}=4.21, \mathrm{SD}=.88)$ for utilizing previous coursework to excel in applied projects; $\mathrm{t}(34)=2.24, \mathrm{p}=.03$.

These results suggest that, overall, students felt more confident in these areas at the end of the semester than they had at the beginning. Areas with statistically significant increases show where the Senior Capstone course may be impacting student confidence in key areas as they prepare to transition from academia to post-graduate jobs. These results were consistent with previous outcomes from similar studies. For instance, Zhang et al. ${ }^{7}$ concluded that "students developed a better sense that engineers should use their skills to solve social problems facing their local community" and "students have reinforced their belief that service and academic coursework should be integrated" for better learning experience. Duffy et al. ${ }^{8}$ reported that students expressed positive influences of service learning projects. The students also strongly 
International Journal for Service Learning in Engineering, Humanitarian Engineering and Social Entrepreneurship Vol. 12, No. 2, pp. 57-80, Fall 2017

ISSN 1555-9033

agreed that they enjoyed learning, learned more from hand-on activities, and reported a preference for working in groups.

TABLE III

PRE- AND POST-TEST STUDENT CONFIDENCE RATINGS

\begin{tabular}{|c|c|c|c|c|c|c|}
\hline Question & Pre & & Post- & & Statistics & Sig \\
\hline & Mean & $S D$ & Mean & $S D$ & & \\
\hline $\begin{array}{l}\text { 1. Create and adapt complex products } \\
\text { and services }\end{array}$ & 3.77 & .81 & 4.03 & .75 & $t(34)=2.49, p=.02$ & Yes \\
\hline $\begin{array}{l}\text { 2. Apply engineering techniques and } \\
\text { design procedures to solve open-ended } \\
\text { problems }\end{array}$ & 3.69 & .83 & 4.23 & .77 & $t(34)=3.93, p=.01$ & Yes \\
\hline $\begin{array}{l}\text { 3. Generate new ideas for } \\
\text { products/services }\end{array}$ & 4.00 & .77 & 4.29 & .67 & $t(34)=2.25, p=.03$ & Yes \\
\hline $\begin{array}{l}\text { 4. Adapt existing products/services } \\
\text { using engineering techniques }\end{array}$ & 3.71 & .83 & 4.11 & .76 & $t(34)=2.91, p=.01$ & Yes \\
\hline $\begin{array}{l}\text { 5. Apply engineering techniques and } \\
\text { skills to solve real-world problems }\end{array}$ & 3.89 & .80 & 4.26 & .82 & $t(34)=2.41, p=.02$ & Yes \\
\hline $\begin{array}{l}\text { 6. Collaborate well with others in team } \\
\text { settings }\end{array}$ & 4.31 & .76 & 4.03 & .95 & $t(34)=-1.89, p=.07$ & No \\
\hline $\begin{array}{l}\text { 7. Communicate effectively with others } \\
\text { in multidisciplinary teams }\end{array}$ & 4.23 & .77 & 4.29 & .83 & $t(34)=0.42, p=.67$ & No \\
\hline $\begin{array}{l}\text { 8. Explain your work to people who are } \\
\text { outside of your field }\end{array}$ & 3.80 & .83 & 4.11 & .68 & $t(34)=1.87, p=.07$ & No \\
\hline $\begin{array}{l}\text { 9. Conduct design and analysis in an } \\
\text { ethical and socially responsible manner }\end{array}$ & 4.06 & .80 & 4.00 & .73 & $t(34)=-0.35, p=.73$ & No \\
\hline $\begin{array}{l}\text { 10. Work in teams where knowledge } \\
\text { from many disciplines must be applied }\end{array}$ & 3.83 & .71 & 4.06 & .94 & $t(34)=1.28, p=.21$ & No \\
\hline $\begin{array}{l}\text { 11. Create and stick to a budget during } \\
\text { a project }\end{array}$ & 3.69 & .76 & 3.71 & 1.05 & $t(34)=0.12, p=.91$ & No \\
\hline 12. Express your ideas in writing & 3.43 & 1.01 & 3.97 & .92 & $t(34)=2.45, p=.02$ & No \\
\hline 13. Express your ideas verbally & 3.71 & .83 & 4.03 & .86 & $t(34)=1.87, p=.07$ & No \\
\hline $\begin{array}{l}\text { 14. Express your ideas clearly in formal } \\
\text { presentations }\end{array}$ & 3.77 & .88 & 3.94 & .84 & $t(34)=0.95, p=.35$ & No \\
\hline $\begin{array}{l}\text { 15. Easily make connections between } \\
\text { market, production, and cost factors } \\
\text { related to the process of product design }\end{array}$ & 3.91 & .87 & 4.15 & .70 & $t(34)=1.24, p=.22$ & No \\
\hline $\begin{array}{l}\text { 16. Utilize your previous coursework to } \\
\text { excel in applied projects }\end{array}$ & 3.85 & .86 & 4.21 & .88 & $t(34)=2.24, p=.03$ & Yes \\
\hline $\begin{array}{l}\text { 17. Transition from school to the job } \\
\text { market }\end{array}$ & 3.77 & .92 & 4.03 & 1.03 & $t(34)=1.47, p=.15$ & No \\
\hline
\end{tabular}

$N=35$, Measured on a "Not Confident at All" $=1$ to "Extremely Confident" $=5$ Scale 


\section{Pre- and Post-test Results: Open-Ended Questions Overview}

As open-ended responses from the pre-test and post-test were analyzed and compared, several common themes emerged. While some trends remained consistent across time, there was growth in several areas. The most frequently mentioned themes are discussed in detail, including key changes in response patterns between the pre- and post-tests.

\section{Pre-test Results}

\section{Pre-test: Most Confident}

1. Educational Background: The pre-test shows that many students began the course with confidence that that knowledge gained through their educational background had already provided them with knowledge of theory and technical skills that could be applied in the workplace (8 of 31). Student examples include projects, internship experiences, GPAs, scholarships, and awards.

2. Problem Solving: Another key area of high student confidence was problem-solving skills (7 of 31). Students were confident using knowledge from coursework to solve realworld problems, like lean production and supply chain issues, by utilizing various mathematical and engineering techniques. Students described confidence in utilizing resources to arrive at solutions, even when the answers or solutions are unclear at first.

3. Working with Others: Response trends in the pre-test also showed that many students felt confident working with others (6 of 31), both in teams of engineers and with professionals in other fields. These students were most confident working with diverse groups of people, explaining that they don't foresee problems working with multidisciplinary teams as they enter the workforce.

4. Lean Manufacturing/Production Planning: In the pre-test, many students expressed confidence in their ability to lower the cost of manufacturing, explaining confidence in skills related to manufacturing, production planning, supply chain, and applying software programs to these processes ( 7 of 31 ).

\section{Pre-test: Least Confident}

1. Communicating Ideas: Many respondents reported difficulty communicating ideas (7 of 31). Some students described difficulty with verbal communication, like explaining ideas to managers or giving presentations, while others described difficulty with written communication for emails or formal reports. Students expressed concerns that communication issues would make it difficult for them to present their ideas in business settings. Some students reported concerns that business English would be different from academic English, potentially making it difficult for them to acclimate to new workplaces.

2. Finding the Right Job: Many students reported apprehension about finding and being selected for a job (5 of 29). Student concerns include finding starting jobs that align with their future interests, navigating the job search as an international student, and appearing competitive to employers when compared against other job candidates.

3. Work Experience: Although many students felt very confident about their educational background as they enter the workplace ( 8 of 31), some students (4 of 30) felt that they lacked work experience outside of academia. 
4. Leadership Skills: Many students were most confident in their abilities to work with others (6 of 31) at the beginning of the semester, but some students (4 of 30) felt that they lacked leadership skills. Students explained that they have done a lot of team-based projects but have little experience leading teams or taking on managerial responsibilities. These students expressed concerns that this would affect their success in managerial or project management roles as they enter the workplace.

\section{Pre-test: Other Student Responses}

There were many responses in the pre-test that did not fall within the top categories.

\begin{tabular}{|l|l|}
\hline Students reported being confident in: & Students reported lacking confidence in: \\
\hline - Adaptability (4 of 31) & - Finance knowledge (2 of 30) \\
- Creativity/Ability to innovate (4 of 31) & - Sales/marketing abilities (2 of 30) \\
- Communication skills (4 of 31) & - Competitiveness when compared with \\
- Applying theory to real-world problems (3 of 31) & other job applicants (3 of 30) \\
\hline
\end{tabular}

\section{Post-test Results}

Post-test: Most Confident

1. Applying Theory to Real-World Problems: The most frequent response trend in the post-test was student confidence in the application of theory to real-world problems ( 7 of 29). This shows an increase from the pre-test, where just 3 of 31 respondents reported this as the area where they were most confident. This data suggests that more students feel confident in this area after they gained the experience from the coursework and projects in the instructor's course.

2. Communicating Ideas: In the post-test, many students reported that they are able to effectively communicate their ideas, noting communication as their greatest area of confidence as they enter the workforce (6 of 29). Of these 6 respondents, 5 of these provided examples of verbal communication. This is noteworthy because communication was the most frequently listed area of low student confidence at the beginning of the semester, with 8 of 30 pre-test respondents reporting that they were least confident in their verbal and written communication skills. This suggests that the course material may have increased student confidence in their ability to communicate their ideas.

3. Educational Background: Similar to the pre-test, many students (5 of 30) reported feeling confident in their educational background. This data suggests that students are relying heavily on educational experiences and successes as they make the transition into the workplace post-graduation.

4. Lean Manufacturing/Production Planning: Consistent with results from the pre-test, many students expressed confidence in their understanding of production planning, supply chain issues, lean manufacturing, and applying software programs to these processes (5 of 29). This was a top area of student confidence in both the pre-test and the post-test, suggesting that students are relying heavily on these technical skills as they enter the workforce. 


\section{Post-test: Least Confident}

1. Market Analysis: Many students in the post-tests reported a lack of confidence in applying market analysis in the field (7 of 26). These students expressed concerns in realworld applications of market analysis and about the difficulties of justifying a new creation in a target market. Students explained that they didn't feel confident in their abilities to match new products with the market and to explain the importance of new products/services as they introduce them to the market.

2. Communicating Ideas: Similar to the pre-test, students in the post-test reported communication as one of their greatest challenges as they prepare to enter the workforce (7 of 26). This is a slight reduction from the pre-test, but remains a top area of concern for these engineering students as they begin their careers. Although more students listed communication as a strength in the post-test (6 of 29) than the pre-test (4 of 31), this may still be an area for focus in the future.

3. Technical Skills: At the end of the semester, 5 of 26 students reported that technical skills are the area where they are least confident. Several respondents in the pre-test and post-test mentioned lacking applied work experience, suggesting that many of these technical skills may be gained while working in the field.

4. Finding the Right Job: Of 26 respondents, 4 reported concerns about choosing a job that aligns well with their long-term goals. Students worried that they had not done enough networking, that they had very little work-experience outside of academia, and that international students could be at a disadvantage in the job market due to high expenses of hiring.

\section{Post-Test: Other Student Responses}

There were many responses in the post-test that did not fall within the top categories.

\begin{tabular}{|l|l|}
\hline Students reported being confident in: & Students reported lacking confidence in: \\
\hline - Creativity/Ability to innovate (2 of 29) & $\bullet \quad$ Finance knowledge (2 of 26) \\
- Adaptability (2 of 29) & $\bullet \quad$ Working with others (2 of 26) \\
- Leadership skills (2 of 29$)$ & $\bullet \quad$ Work experience (2 of 26$)$ \\
- Sales/Marketing skills (2 of 29$)$ & \\
- Working with others (2 of 29$)$ & \\
- Performing market analyses (2 of 29$)$ & \\
- Combining techniques to solve problems (2 of 29) & \\
\hline
\end{tabular}

\section{Mid-Semester Survey Results Summaries}

The following open-ended questions were given to students in the middle of the semester while they were actively working on the applied course project. The following responses have been analyzed thematically and broken down into key themes.

\section{Question 1:}

How did the service involved in this project affect the way you worked on it? Was the amount of effort on this project greater than for projects not involving service? Explain. 
- Service was helpful: Many students (11 of 28) indicated that the service involved in the project was helpful. Students explained that service gave a clear vision of what the goal was and why the project was being conducted. Students reported that the service component served as a motivator because the outcome of the project mattered to someone else too.

- Service increased effort required: Many students (9 of 28) indicated that the service element increased the amount of effort involved in this project. Students explained that they put more effort into the project because it was a real-world situation and there were many stakeholders that could be affected by the results. Respondents noted that multiple trips to the project's location also increased the effort required.

- Service did not change effort required: Some students (6 of 28) reported that the service element did not affect the amount of effort required for the project or the way that it was conducted.

- Service made project more difficult: A few students (2 of 28) did not like the service element. One felt that it made the scope of the project more difficult to understand, while the other would have preferred to choose a different project topic without service instead of being assigned this project. Overall, the service element seems to have been wellreceived by students even though it may have required greater effort.

\section{Question 2:}

\section{How did this project help you to solve real-world problems?}

- The vast majority of the respondents found the project to be helpful practice of solving real world problems (28 of 29). Students described the project, an assignment that asked students to come up with a solution to a real-world problem, as an opportunity to apply engineering theory in a realistic context.

- Students liked this opportunity to implement what had been learned throughout their educational careers and to combine different techniques. Several respondents felt that this project exposed them to the types of real-world problems that they will be likely to encounter and helped them learn how to solve them. Students enjoyed the opportunity to apply different problem-solving approaches to optimize the outcomes and minimize the time spent.

- Students reported that this project helped them to see the perspectives of workers and businesses, enabling them to see how processes can be improved for these individuals. Dealing with communication and scheduling issues allowed them to understand what is involved in working with multiple stakeholders.

- Students appreciated the experience making business decisions with real data and real money. This encouraged focus on details like the market, the cost of manufacturing, shipping, selling products, end user needs, and producer needs. Students reported that this emphasized the amount of planning involved when creating a product or a business.

- Many students reported that they will put this project experience on their resumes to demonstrate ability to solve real-world problems to future employers. 
International Journal for Service Learning in Engineering, Humanitarian Engineering and Social Entrepreneurship

Vol. 12, No. 2, pp. 57-80, Fall 2017

ISSN 1555-9033

\section{Question 3:}

\section{Did your team work together effectively? What did this project teach you about working} with others?

- Overall, students gained experience working in collaborative teams, making decisions and solving problems with others. Some students found this to be difficult, while others found it to be helpful experience that is may be similar to what they will experience in future jobs.

- Most students surveyed reported effective teamwork in the project (24 of 29). These students reported learning about time management, dividing up the workload, delegating tasks, and establishing group leadership. Students learned that communication is a key component of successful teamwork.

○ Students emphasized the importance of idea sharing in group settings. Many teams used group brainstorming to generate new ideas for solutions. Students learned that each group member brings different ideas and strengths and that these should be understood in order work effectively as a team.

- Some students reported having to change their own preferences or habits in order to conform with group norms. Examples include scheduling, preferred communication channels, and work styles.

- Several students explained that meeting in-person periodically helped to ensure that teams made decisions with the input of all members. Students reported that in-person meetings generated many new ideas.

- Some students did not report successful teamwork during the project (5 of 29). Some reasons included lack of group leadership, division of the group into siloed sub groups, ineffective team members, and lack of respect between teammates.

\section{Question 4:}

What was the most difficult part of the project?

- Design: Students who found the design component to be the most difficult part of the project (7 of 29) described difficulty generating innovative design ideas and actually creating the device. These students explained that it was a challenge to design items that can work for everyone, can be produced for a low cost, and have many new features.

- Project Logistics: Students who reported that project logistics was the most difficult part of the project ( 5 of 29) explained that they struggled to comply with deadlines, fit their work within the formats, and fix scheduling mistakes. Students described some confusion about professor expectations and about the scope of the project.

- Report: Students who found writing the report to be the most difficult part of the project (4 of 29) explained that there was a lot of information to be organized and it was difficult to explain ideas in enough detail. These students found the research portion to be difficult.

- Marketing: Students who found marketing to be the most difficult (3 of 29) explained that they found it difficult to forecast the behavior of their product in the target market.

- Teamwork: Students who reported that working with others was the most difficult part of this project (3 of 29) explained difficulty delegating responsibilities among team members, dealing with interpersonal conflicts, and managing irresponsible team members. 
- Implementation: Students who found that implementation was the most difficult aspect of this project (3 of 29) explained that it was much easier to think of great solutions that it was to implement them in the real world. A student reported that it was difficult to test potential solutions in order to decide which will work in reality. The realities of production also were challenging for these students.

\section{Question 5:}

\section{How did this project prepare you for post-graduate work?}

- Students reported that this project was their first opportunity to solve a real-world problem and to apply what has been learned in classes, providing a preview of what will be required on-the-job after graduation.

- Students reported improvement in the following skills as a result of this project:

- Market research: Students explained that this project gave them experience designing products for a specific market, a skill that will be important in future jobs.

- Detail orientation: Students explained that this project required them to focus on the many details involved in design and implementation when conducting a realworld project. This emphasized the importance of careful planning, managing time well, and communicating effectively.

- Communication: Students describe improvements in written and oral communication. This includes interpersonal interactions within teams as well as communications with clients and stakeholders, such as presentations.

- Teamwork: Students explain that this project helped them to work in teams, accept others' ideas, discuss problematic material, and to communicate effectively to get work done.

- Making decisions with multiple stakeholders: Students explain that working in collaborative teams internally and with external businesses gave them experience making decisions that can affect many people. Students found this simulation of real-world circumstances to be good preparation for post-graduate work.

\section{DISCUSSION}

Improving student engagement in engineering courses is a challenging task for engineering educators. Our experiences in this project showed that without spending extra times or removing our course materials, the presented projects could be integrated into the course. The most critical part of this project was to find partners and then work with the partners to fit possible projects to the course specific outcomes. The size of the projects should be right size and make the students excited. Site visits must be planned based on their school schedule. Several site visits and meetings with the partners are essential before semesters begins. The students point of view, these projects require more time to complete than their regular course project which is acceptable for the students because of the projects are associated with the real issues resulting more research and discussions with their group members. However, students showed increases in several areas over the course of the semester, including confidence in communication skills and ability to apply engineering theory to real-world problems. 
International Journal for Service Learning in Engineering, Humanitarian Engineering and Social Entrepreneurship Vol. 12, No. 2, pp. 57-80, Fall 2017

ISSN 1555-9033

Our primary goal is to keep this program active to create sustainable and technical solutions for our community. In collaboration with the SIUE's Center for Faculty Development and Innovation, a pilot workshop will be conducted with cooperating faculty and refined during the project based on input from the faculty and project findings. A final workshop, open to all SIUE faculty, will be presented, along with a plan to assist in the design and development of other service-learning-based courses in engineering education. The results will also be disseminated to the general public via the IE Senior Design Website created prior to the start of the course and SIUE Student Involvement Center. In addition to these, the results of the proposed project will also be presented at the yearly open house exhibition organized by the School of Engineering at SIUE to familiarize and motivate high school students to pursue a bachelor's degree in engineering at SIUE. However, this project that began with institutional support which contributed to success of the program in the short term requires financial support for long term success. For the sustainability, a few approaches are being discussed among the faculty members in the department. These approaches include, clients can be charged a fee for the services provided. This could be a fixed fee based on size of the project and community. Another approach would be to ask grant or gift from alumni. We will also search to find if any local, state, or federal agencies provide funding for the program for the long term.

What we learned from this project is finding the right project for our students and community partners is challenging. Planning and detailed coordination with the community were critical. During the project, the instructor's responsibility must be a bridge between sponsors and students. Lack of communication between these two groups results project delayed or poor outcome. The most difficult part during the project was to provide site visits to the students. Not all students had transportation and we had to arrange transportation service for those students regularly each week. A manager from each community partner visited our institution to answer students' questions. This was very helpful for those who could not make the site visits because of their schedule conflicts and other reasons. Project topic and size must be also very important for the students to successfully complete within reasonable time period.

\section{CONCLUSIONS}

The integration of service-learning has been developed in the senior capstone design course in the industrial engineering undergraduate curriculum at SIUE. The potential partners for this project were identified and then, the selected partners were involved during the projects by providing office hours every week to discuss the teams' progresses. Quantitative deliverables were presented to the project partners as well as the other faculty members and IPAC members in the department. At the completion of these service learning projects, the students liked this opportunity to implement what had been learned throughout their educational careers and to combine different techniques. Several respondents felt that this project exposed them to the types of real-world problems that they will be likely to encounter and helped them learn how to solve them. These projects also helped to meet several ABET program outcomes. One of our partners expressed his appreciation as follow: "I thoroughly enjoyed working with your students last semester on their design projects. It is very valuable for Schnucks to capture the perspectives of people outside of our organization to continuously improve how we do business. Your students brought up many valid points on how millennials' shopping habits totally differ from many of 
the customers we traditionally target. As a result of the observations made and providing solutions by your students, we have submitted many of their recommendations to various merchandising groups within our organization. The project pitch outs that I was most impressed with were the S-Mart Stocking System from group \#1, the Produce Stocking Cart from group \#2, the Cloud Cart from group \#7 and the SMART Cart from group \#8. Group \#1 had the strongest impact on me because of the prototype/scaled model. It was easy to demonstrate the features and everything they presented regarding how the cart was to be used was tangible. The concepts for groups\#2, \#7 and \#8 were great. Their presentations were pretty good for the most part, however, a prototype/scaled model should be a requirement. I especially feel that way with anything that involves software. Using some kind of terminal emulator to walk the audience through the shopping experience would have made for a very powerful demonstration for groups \#7 and \#8."

The integration of service learning into the curriculum is a first step towards undergraduate curriculum reform in the XX. This process added broadness to the course content and made a positive contribution to the curriculum development.

\section{ACKNOWLEDGMENTS}

The authors would like to thank the Excellence in Undergraduate Education (EUE) program at SIUE for the financial support, and Mr. Ric Resendez and Ms. April L Imming for their assistance in the projects presented in this paper.

\section{REFERENCES}

[1] ABET. "Criteria for Accrediting Engineering Programs - Effective for Evaluations During the 2016-2017 Accreditation Cycle." http://www.abet.org/accreditation/accreditation-criteria/criteria-for-accreditingengineering-programs-2016-2017/.

[2] Berry, J., M. "An Examination of Partnership Development between Community Service Agencies and an Institution of Higher Education: Implications for Service-Learning ": Ohio State University, Columbus, OH., 2009.

[3] Eyler, J., Giles, G.E., Jr. . Where's the Learning in Service-Learning. San Francisco: Jossey-Bass Publishers, 1999.

[4] Howard, J.P.F. "Academic Service Learning: A Counter Normative Pedagogy." New Directions for Teaching and Learning 73 (2008): 21-29.

[5] Oakes, W. "Service Learning in Engineering: A Resource Guidebook." Campus Compact, Brown University, 2004.

[6] Strage, A. . " Service-Learning: Enhancing Student Learning Outcomes in a CollegeLevel Lecture ". Course Michigan Journal of Community Service Learning 7 (2000): 513.

[7] Zhang, X., Gartner, N., Gunes, O., Ting, J. M. "Integrating Service Learning Projects into Civil Engineering Courses." International Journal for Service Learning in Engineering Humanitarian Engineering and Social Entrepreneurship 2, no. 1 (2005): 4463.

[8] J. Duffy, L. Barrington, C. West, M. Heredia and C. Barry. Service-Learning Integrated throughout a College of Engineering (SLICE),Advances in Engineering Education, (inpress), 2011,special issue on NSF-Department Level Reform. 


\section{Appendix A: Pre-and Post- Survey- Spring 2017}

\section{Last 4 digits of your Student ID:}

\section{How confident are you in your ability to do the following:}

Create and adapt complex products and services

$\begin{array}{ccccc}1 & 2 & 3 & 4 & 5 \\ \text { Not Confident } & \text { Not Very } & \text { Confident } & \text { Very Confident } & \text { Extremely } \\ \text { At All } & \text { Confident } & & & \text { Confident }\end{array}$

Apply engineering techniques and design procedures to solve open-ended problems

$\begin{array}{ccccc}1 & 2 & 3 & 4 & 5 \\ \text { Not Confident } & \text { Not Very } & \text { Confident } & \text { Very Confident } & \text { Extremely } \\ \text { At All } & \text { Confident } & & & \text { Confident }\end{array}$

Generate new ideas for products/services

$\begin{array}{ccccc}1 & 2 & 3 & 4 & 5 \\ \text { Not Confident } & \text { Not Very } & \text { Confident } & \text { Very Confident } & \text { Extremely } \\ \text { At All } & \text { Confident } & & & \text { Confident }\end{array}$

Adapt existing products/services using engineering techniques

$\begin{array}{ccccc}1 & 2 & 3 & 4 & 5 \\ \text { Not Confident } & \text { Not Very } & \text { Confident } & \text { Very Confident } & \text { Extremely } \\ \text { At All } & \text { Confident } & & & \text { Confident }\end{array}$

Apply engineering techniques and skills to solve real-world problems

$\begin{array}{lllll}1 & 2 & 3 & 4 & 5\end{array}$

$\begin{array}{lllll}\text { Not Confident } & \text { Not Very } & \text { Confident } & \text { Very Confident } & \text { Extremely }\end{array}$ At All Confident

Confident
Collaborate well with others in team settings

$\begin{array}{ccccc}1 & 2 & 3 & 4 & 5 \\ \text { Not Confident } & \text { Not Very } & \text { Confident } & \text { Very Confident } & \text { Extremely } \\ \text { At All } & \text { Confident } & & & \text { Confident }\end{array}$


Communicate effectively with others in multidisciplinary teams
1
2
3

Not Very

Confident

Confident

Very Confident

Extremely

Confident

Explain your work to people who are outside of your field

$\begin{array}{ccccc}1 & 2 & 3 & 4 & 5 \\ \text { Not Confident } & \text { Not Very } & \text { Confident } & \text { Very Confident } & \text { Extremely } \\ \text { At All } & \text { Confident } & & & \text { Confident }\end{array}$

Conduct design and analysis in an ethical and socially responsible manner

$\begin{array}{ccccc}1 & 2 & 3 & 4 & 5 \\ \text { Not Confident } & \text { Not Very } & \text { Confident } & \text { Very Confident } & \text { Extremely } \\ \text { At All } & \text { Confident } & & & \text { Confident }\end{array}$

Work in teams where knowledge from many disciplines must be applied

$\begin{array}{ccccc}1 & 2 & 3 & 4 & 5 \\ \text { Not Confident } & \text { Not Very } & \text { Confident } & \text { Very Confident } & \text { Extremely } \\ \text { At All } & \text { Confident } & & & \text { Confident }\end{array}$

Create and stick to a budget during a project

$\begin{array}{ccccc}1 & 2 & 3 & 4 & 5 \\ \text { Not Confident } & \text { Not Very } & \text { Confident } & \text { Very Confident } & \text { Extremely } \\ \text { At All } & \text { Confident } & & & \text { Confident }\end{array}$

Express your ideas in writing

$\begin{array}{ccccc}1 & 2 & 3 & 4 & 5 \\ \text { Not Confident } & \text { Not Very } & \text { Confident } & \text { Very Confident } & \text { Extremely } \\ \text { At All } & \text { Confident } & & & \text { Confident }\end{array}$

Express your ideas verbally

$\begin{array}{ccccc}1 & 2 & 3 & 4 & 5 \\ \text { Not Confident } & \text { Not Very } & \text { Confident } & \text { Very Confident } & \text { Extremely } \\ \text { At All } & \text { Confident } & & & \text { Confident }\end{array}$


Express your ideas clearly in formal presentations

$1-2$

Not Confident Not Very Confident

At All

Confident

4

Very Confident
5

Extremely

Confident

Easily make connections between market, production, and cost factors related to the process of product design

$\begin{array}{ccccc}1 & 2 & 3 & 4 & 5 \\ \text { Not Confident } & \text { Not Very } & \text { Confident } & \text { Very Confident } & \text { Extremely } \\ \text { At All } & \text { Confident } & & & \text { Confident }\end{array}$

Utilize your previous coursework to excel in applied projects

$\begin{array}{ccccc}1 & 2 & 3 & 4 & 5 \\ \text { Not Confident } & \text { Not Very } & \text { Confident } & \text { Very Confident } & \text { Extremely } \\ \text { At All } & \text { Confident } & & & \text { Confident }\end{array}$

Transition from school to the job market

$\begin{array}{ccccc}1 & 2 & 3 & 4 & 5 \\ \text { Not Confident } & \text { Not Very } & \text { Confident } & \text { Very Confident } & \text { Extremely } \\ \text { At All } & \text { Confident } & & & \text { Confident }\end{array}$

What do you feel most confident about as you prepare to transition from your education to your career? Explain.

What do you feel least confident about as you prepare to transition from your education to your career? Explain. 